\title{
A Conceptual Framework for Choosing Target Species for Wildlife-Inclusive Urban Design
}

\author{
Beate Apfelbeck ${ }^{1,2, *}$, Christine Jakoby ${ }^{3}$, Maximilian Hanusch ${ }^{1,2}{ }^{\mathbb{D}}$, Emanuel Boas Steffani ${ }^{1}$, \\ Thomas E. Hauck ${ }^{3}$ and Wolfgang W. Weisser ${ }^{1}$ \\ 1 Terrestrial Ecology Research Group, Department of Ecology and Ecosystem Management, \\ School of Life Sciences Weihenstephan, Technische Universität München, D-85354 Freising, Germany; \\ maximilian.hanusch@sbg.ac.at (M.H.); emanuel.boas.steffani@tum.de (E.B.S.); \\ wolfgang.weisser@tum.de (W.W.W.) \\ 2 Department of Biosciences, University of Salzburg, 5020 Salzburg, Austria \\ 3 Department for Open Space Planning, University of Kassel, 34127 Kassel, Germany; \\ christine.jakoby@asl.uni-kassel.de (C.J.); thomas.hauck@asl.uni-kassel.de (T.E.H.) \\ * Correspondence: beateanna.apfelbeck@sbg.at.ac
}

Received: 1 November 2019; Accepted: 2 December 2019; Published: 6 December 2019

\begin{abstract}
Recent research has highlighted the significance of cities for biodiversity, making them important places for conservation in their own right. Current conservation approaches in cities are mostly defensive. Thus, they focus on remnant pockets of natural areas or try to protect particular species that occur in the built environment. These approaches are vulnerable to further urban development and do not create habitats. An alternative strategy is to make wildlife an integral part of urban development and thereby create a new habitat in the built-up area. Here we address the challenge of choosing target species for such wildlife-inclusive urban design. The starting point of our conceptual framework is the regional species pool, which can be obtained from geo-referenced species data. The existing habitat types on and around the development site and dispersal barriers limit the species numbers to the local species potential. In the next step, the site's potential for each species is analyzed-how can it be upgraded to host species given the planned development and the life-cycle of the species? For the final choice of target species, traits related to the human-animal interaction are considered. We suggest that stakeholders will be involved in the final species selection. Our approach differs from existing practice, such as expert choice of priority species, by (1) representing an open process where many species are potential targets of conservation, (2) the involvement of stakeholders in a participatory way. Our approach can also be used at larger spatial scales such as quarters or entire cities.
\end{abstract}

Keywords: urban planning; wildlife-inclusive urban design; human-wildlife interactions; biodiversity; urban design; stakeholder participation; geo-referenced species data; GIS

\section{Introduction}

Today, urbanization is one of the major threats to biodiversity [1]. Thus, it may be surprising that biodiversity is often quite high in urban areas, especially in comparison to intensively managed agricultural areas [2]. Indeed, many species frequently occur in cities and some species may even thrive in urban areas (e.g., peregrine falcons (Falco peregrinus) [3]). In addition, cities have often been built in naturally biodiverse areas $[4,5]$. As humans and animals share common spaces, cities have an important role in the nature experience of city dwellers, including decision-makers [6]. Therefore, cities are important for the conservation of biodiversity per se and as a cradle for future conservationists.

Nevertheless, cities do not offer space for all species [7]. Although species recruit from the regional species pool, species traits and human decisions determine which species eventually live in cities [8,9]. 
City structure has a huge impact on biodiversity in cities [10] and often species are lost when cities densify. Urban densification results in the reduction of green space in many cities and even endangers species that are closely associated with people and urban areas. An example is the house sparrow (Passer domesticus), which is in a rapid decline in cities all around the world [11,12].

Consequently, if we want to retain biodiversity within cities and benefit from its positive effects on conservation, human wellbeing and other ecosystem services [13], biodiversity has to be directly considered in urban development. For example, green areas such as parks could be developed to be better suited to wildlife and corridors could be kept to connect, e.g., forest fragments. So far, however, biodiversity often has a low priority in city planning and, in particular, animals play a minor role [14]. As a result, current green infrastructure may often have limited value for animals [15]. Recently, several approaches have been put forward to include biodiversity into urban planning and design, such as 'biodiversity-sensitive urban design' [16] and 'animal-aided design' [17], also see [18]. While all of these approaches acknowledge the importance of land sparing strategies, i.e., zoning of important wildlife habitat, they also consider the entire city as a potential habitat for species, including the built-up area. Especially in cities where little natural area is left, such land-sharing approaches are necessary to retain biodiversity within cities.

However, it is often not obvious which species should be considered in urban development projects. In conservation, there is a longstanding and ongoing debate about the primary objective of conservation [19]. Since avoiding the extinction of species is the prime concern of conservation, the development of strategies for particular target species is one of the oldest and most successful approaches in conservation biology [20]. An alternative approach is to conserve entire habitats, with the rationale that a functioning ecosystem may provide the highest benefits in terms of both biodiversity and ecosystem services [20]. Inbetween these two alternatives are approaches where particular species are representative of other species or particular ecosystems (umbrella or indicator species). Thus theoretically, a targeted approach of species conservation can be combined with the preservation of many species at the same time. However, in practice, this approach often does not produce the expected results, e.g., [21,22].

Within cities, a habitat approach is only possible where there are remnants of original habitats that are still intact or can be restored. Built-up areas are considered as novel urban ecosystems that are not equivalent to any existing natural habitat [23]. Thus, habitat approaches cannot be implemented in built-up areas. Instead, integrative approaches are required that allow cohabitation of humans and animals on the same site. Wildlife-inclusive urban design therefore mostly focuses on individual species. The aim is to create a habitat for these species in the built environment by analyzing their life-cycle and providing all the resources the species needs [17]. Importantly, these habitats are hybrid habitats where the resources are a mixture of natural and man-made. For example, birds may breed in natural cavities in old trees or in the facade of a building. The seeds they eat may come from plant species planted by humans. The water and sand bath they use can have a dual function and also serve human needs, e.g., as a fountain and a path. These habitats, albeit often small, may then serve as patches for a network in the urban matrix, and become important for nature experience [24].

Choosing target species for conservation is traditionally left to expert professionals such as biologists working for the government or conservation non-government organizations (NGOs). Species selection is, therefore, based largely, if not exclusively, on conservation needs. Thus, target species are often either strongly threatened or protected by law [25]. In such an experts' choice, there is little involvement of other stakeholders, such as the people living on or near the property where the conservation action takes place. 'Community-based conservation' has been introduced and extensively discussed in the 1990s in the context of indigenous communities in natural environments [26,27]. Nevertheless, most conservation efforts, including those in cities, still rely on experts. However, urban areas are socio-ecological systems, and therefore 'conservation and management of urban biodiversity is about people' [28]. Thus, stakeholder involvement for target species selection is an important tool to increase the chances of positive human-wildlife interactions later. 
Stakeholder involvement implies that conservation targets (target species) have to be chosen together with built environment professionals, but also other stakeholders. Built environment professionals, such as engineers or architects, are important to make sure that target species requirements do not conflict with design. Stakeholder involvement may also include residents of a housing estate. For new developments, the involvement of residents during target species selection is not possible, however, later involvement is crucial, e.g., through environmental education programs and stewardship. For redevelopment projects, residents can be already involved during target species selection to promote understanding and stewardship early on [29].

Accordingly, species selection for urban development needs to be ecologically sensible, locally possible and agreed upon by stakeholders. Here, we develop a framework for selecting target species for wildlife-inclusive urban design. It considers both ecological and socio-cultural criteria for development projects in the built environment. Our conceptual framework involves the use of big data, structured decision-making, expert opinion, and participative approaches. We believe that this framework can broaden the scope of conservation projects in the urban environment and make them more acceptable to city dwellers. The use of big data on species occurrences will increase the range of species that can be targeted including more common species that are declining in the urban environment, as well as rare species that would normally not be targeted. When a participatory approach is used, conservation projects are likely to meet with more support by city dwellers. This is different from most current conservation processes where only conservation experts decide on what species need to be prioritized. In our proposed approach, conservation experts can make suggestions, but the stakeholders ultimately decide on target species.

In the following, we will describe our species selection framework step by step, starting from the regional species pool that allows identification of candidate species up to the final selection of target species.

\section{The Species Selection Framework}

The starting point of our conceptual framework is the observation that many more species could live at a particular place in the city, not just those that already live there. This is because current species occurrences are often constrained by a lack of habitat features that could be added during development. Thus, it is the regional species pool, which can be obtained from geo-referenced species data, that needs to be searched when target species for a particular urban development project are sought. The available habitat types on and around the development site, the dispersal potential of species, barriers in the environment, and the living requirements of the species all limit the species number to the local species potential. For the final choice of target species, traits related to the human-animal interaction are considered. We suggest that experts, e.g., ecologists or environmental consultants, make some recommendations, but that there is a participatory process so that stakeholders will be involved in species selection (Figure 1). 


\section{A. Ecological criteria}

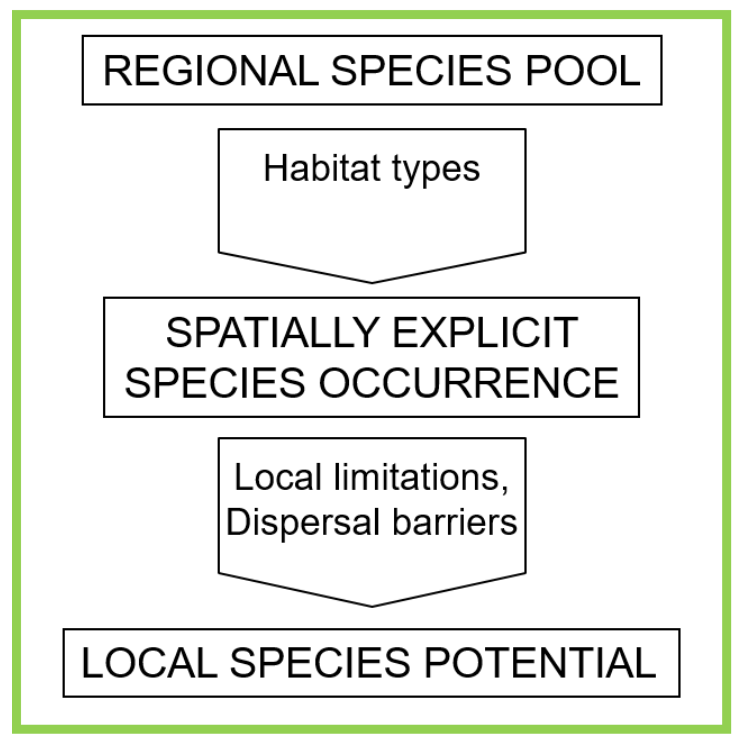

\section{B. Socio-cultural criteria, Participation}

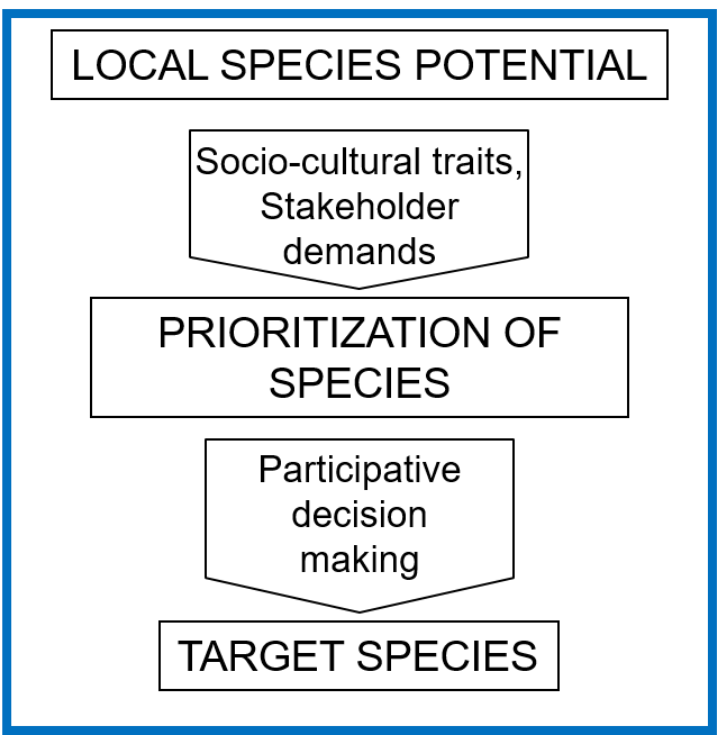

Figure 1. Schematic representation of our proposed framework for target species selection for urban development projects. The process of selection can be divided into a selection process based on ecological criteria (a), which precedes socio-cultural considerations (b).

\subsection{From the Regional Species Pool to the Local Species Potential}

\subsubsection{Regional Species Pool: Use of Geo-Referenced Species Occurrence Data}

The regional species pool determines which species may occur at a project site. Publicly available species monitoring data can be analyzed to create a list of species that have been recorded in the city of interest. Such data are available in most countries, even though the way such data are available differs from country to country and between regions within countries. Differences may occur with respect to which taxa are contained in the database, data sources and the information stored in each record. In Germany for example, the 16 German states (Bundesländer) each have their own database (or none), and differ widely in how and which species data are available, ranging from having no public database yet (state of Berlin), recording only certain vertebrate taxa (state Baden-Württemberg) to data on all taxa (e.g., Bavaria, Hamburg). In addition, there are global databases such as the Global Information Facility (GBIF) [30], which offers a huge database of global species monitoring data. Other potential resources are data from authorities from a variety of sources, such as environmental impact assessments (EIAs), publicly funded monitoring schemes or volunteers, such as birders. With the rise in global, national and regional databases, such species occurrence data are becoming more and more available. While such data are routinely used in research projects, e.g., to calculate species distribution maps for research on the effects of climate change, they are not frequently used for local conservation projects.

Publicly available data on species occurrences have some limitations [31,32]. Species occurrence data represent presence data and stem from different sources with varying monitoring efforts. Therefore, they are associated with two types of errors, false absence data, and false presence data. These errors are common in citizen science data and remediation approaches have been developed. Going into these goes beyond the purpose of the present paper. It is likely, however, that easy-to-use methods to deal with the most common data problems will be soon available. In addition, with the increased use of public databases, data quality is likely to increase as more and more quality control measures will be implemented. 
To overcome some of the problems associated with data quality we suggest using a large-scale analysis, to avoid relevant species being overlooked because of false absence data due to low monitoring effort. For the analysis shown below, we selected a $50 \mathrm{~km}$ radius around the project site. Using such a large scale will also address the problem of false presence data, provided that not all observers make the same identification errors. The result of the analysis will be a map with all point locations where species have been recorded in the surroundings of the project site. Some of the species will have been recorded close to the project site, while others will have only been recorded further away.

We tested the availability of data in six major German cities and their surroundings (Hamburg, Hannover, Ingolstadt, Kaiserslautern, Magdeburg, Frankfurt) affecting eleven German federal states. In total 3,621,709 occurrence records of animal species could be obtained from local authorities, the Arachnologische Gesellschaft (AraGes) and GBIF. After clean-up and processing (see Appendix A for a description of methods), 3,344,213 occurrences recorded between 1980 to 2019 were analyzed. Based on these records we estimated regional species pools at different distances around the project sites.

The availability of species occurrence data differed between cities with an average of $557,368 \pm 375,581$ occurrence records within the $50 \mathrm{~km}$ radius. Sampling density was at least 16.4 species records per $\mathrm{km}^{2}$ (Magdeburg) with a maximum of 140 species records per $\mathrm{km}^{2}$ (Frankfurt). On average $4860 \pm 1623$ different taxa were recorded for each city belonging to 34 taxonomical classes. These numbers show that publicly available occurrence data includes many sightings of a plethora of taxonomic groups rather than numerous sightings of only a few attractive and, therefore, easy-to-spot species (also see Figure A1 in Appendix A for an overview of the diversity of species records at each project site). We then tested how large the radius around a project site has to be in order to obtain a certain percentage of the total species richness of the $50 \mathrm{~km}$ circle. Increasing the distance from the project sites increases the area of the circle within which species can be encountered. Within an average range of $7 \pm 1.5 \mathrm{~km}$ around the project site already 50 percent of total species diversity could be found (Figure 2). Increasing this range to $36.25 \mathrm{~km} \pm 4.17 \mathrm{~km}$ led to the inclusion of $90 \%$ of total species diversity.

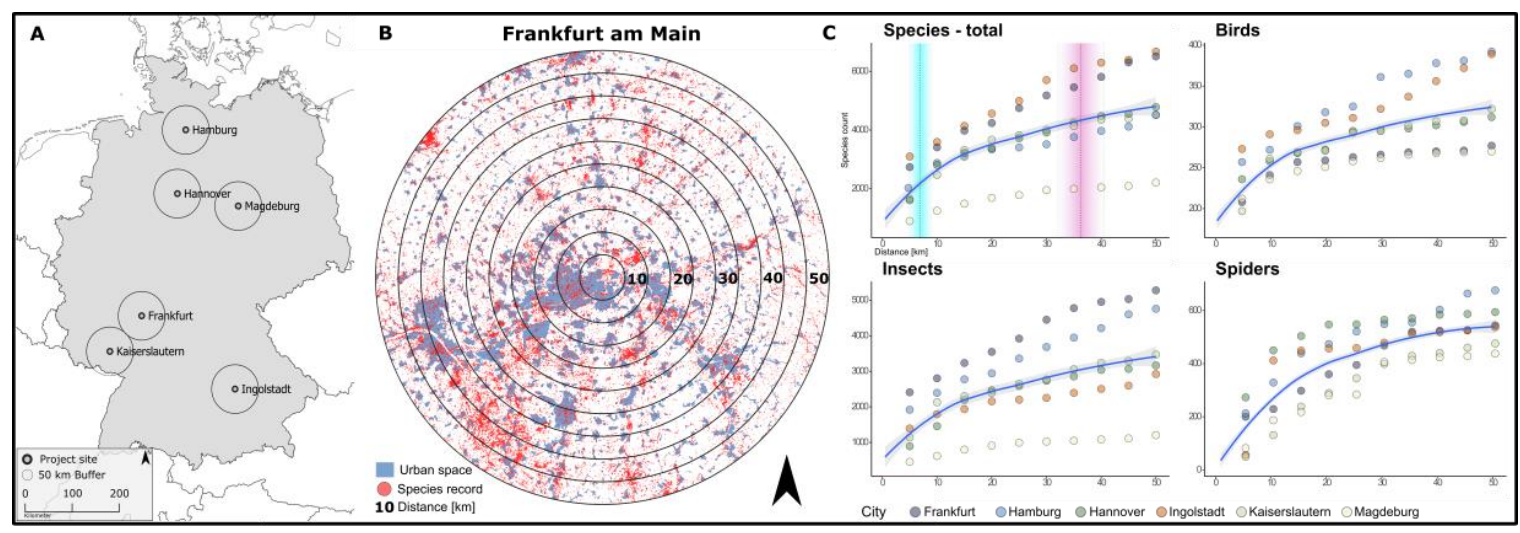

Figure 2. Using publicly available data to obtain a regional species pool. Case study of six project sites within six different German cities. (a) Map of the six project sites and their respective circular $50 \mathrm{~km}$ buffers. (b) Schematic overview of regional species pools around a project site for the example Frankfurt am Main. Multiple buffers were analyzed at increasing distances from the project site (black circles). These buffers were intersected with geo-referenced species occurrence records (red dots) to estimate regional species pools. Blue polygons indicate urban areas. (c) Dependence of species counts of four taxonomic groups on the distance to the project site (radius of buffer) for the six German cities. Blue lines indicate regressions and $95 \%$ confidence intervals. Dotted lines show average values and standard deviations for distances in which 50\% (turquoise) and 90\% (magenta) of total taxonomic diversity can be found.

For wildlife-inclusive urban design, only a few selected species will be proposed to stakeholders as potential target species. Our analysis shows that even in a comparably small area of only a few 
square kilometers regional species pools can be estimated that comprise a multitude of potential target species. We, therefore, see the use of publicly available species records as a valid tool that allows the estimation of regional species pools and helps to identify target species.

\subsubsection{Spatially Explicit Species Occurrences: Locating Species according to Habitat Type}

After the regional species pool and a corresponding map have been established, there are two types of species. First, there are those species that have been recorded close to the project site so that it appears likely for them to reach the site by their own means, assuming there are no dispersal barriers (species of the focal area). Second, there are species that have been recorded only further away from the project site, at a distance too far to reach it (species outside the focal area, Figure 3). To which of these categories a particular species belongs does not only depend on the location where it has been located, but also on its dispersal power. The distance a species can move varies between species and, in particular, between modes of dispersal. A species that can fly will be able to travel further than species that need to walk or to crawl. For migrating birds, for example, a distance of $50 \mathrm{~km}$ does not represent a challenge, except for migration barriers, while for a toad a distance of $1500 \mathrm{~m}$ may be the maximum it can disperse (e.g., [33]). Thus, the focal area will be species-specific. To facilitate the analysis, we suggest to pool species of the same taxon and dispersal mode when deciding on the focal area. For example, a single circular focal area for all songbirds with a radius of $50 \mathrm{~km}$ around the project site, as well as a (separate) focal area for all amphibians with a radius of $2 \mathrm{~km}$ around the project site [34].

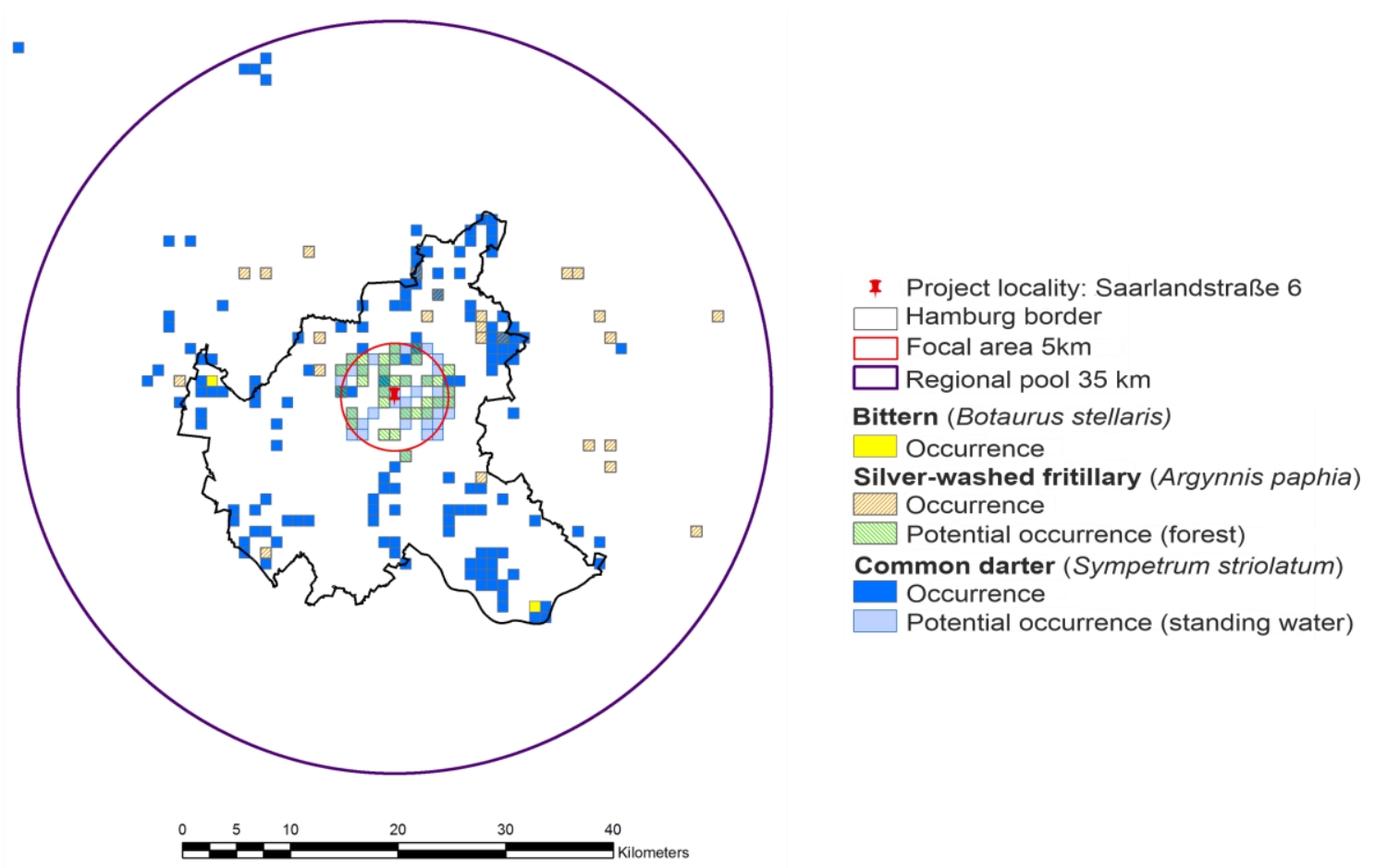

Figure 3. Using habitat maps to infer the potential occurrence of species when the species occurrence data are not complete. The illustration shows the city borders of Hamburg (black line) and the occurrence of three species (bittern, silver-washed fritillary, common darter) within a $35 \mathrm{~km}$ area around the project site (violet outer line). We assume that all three species can colonize the project site when they occur at a distance of $5 \mathrm{~km}$ or less to the project site (focal area, red line). A habitat map (not shown) was used to find sites of potential occurrences of the three species. For two of the species, suitable habitats were found within the focal area (indicated as potential occurrences) while for one species (bittern) no suitable habitat was found within the focal area. In this example, both the silver-washed fritillary and the common darter would be added to the list of potential target species. 
Importantly, species of the regional species pool should not be discarded at this stage, even when they occur only outside their respective focal area. Indeed, these species may occur within the focal area but have not been recorded there (false absence data). We suggest to check whether the typical habitat of these species exists within the focal area. If so, there is the possibility that the species does, in fact, occur in the focal area and the species should be kept as a potential target species. For example, a species that has been recorded in remnants of small forest outside the focal area, but not in similar remnants within the focal area, should be kept as a potential target species, as it is possible that it was not recorded in these remnants due to lack of monitoring. Thus, in addition to point locations of species, it is necessary to use the information on the distribution of habitats in the area surrounding a project site. Again, such information is generally available but differs in quality and detail (see Figure 3 for an example). Whether or not such an approach is appropriate for a particular species will depend on how closely the species is associated with a particular habitat.

\subsubsection{Local Species Potential: Site Limitations and Dispersal Barriers}

At this stage, there is a list of species that at least theoretically can reach the project site by their own means. However, not all of the species of this reduced regional species pool will be able to reach and successfully colonize the project site. Limitations are set by the ability (and willingness) of the developer to realize necessary habitat structures at the project site, the habitat structures in the surroundings of the project site, and the likelihood of a species to reach the project site given existing dispersal barriers. In the next step, these limitations need to be analyzed.

First, the site's potential for each species needs to be considered-which habitat features exist and how can they be upgraded for a target species, given the details of the development and the life-cycle of the species? Here, we need to distinguish between habitat requirements that cannot be achieved unless they are already present and conserved and those that could be implemented by the developer through landscaping. For example, old mature trees with cavities provide important habitat for birds, bats, and other mammals and arthropods in urban areas [35-41], but cannot be provided if not already present. On the other hand, vegetation cover and structure, which are also important determinants of species richness and abundance of birds and arthropods in urban landscapes [10,42,43], can be included in landscape plans. Which habitat structures are required depends on the life-cycle of the target species. For example, diet [44-50], foraging mode and strata [51-53], and the location of breeding and resting places $[44-46,48,54]$ influence whether a species is able to live in a particular urban area. Another important factor to consider is pollution, including noise and light [55-61]. Thus, even if a developer is willing to create conditions suitable for a species, the species may be too sensitive against disturbances to survive in the urban area.

Second, the survival of the species at the project site will not only depend on what exists and what the developer plans, but also on the available habitat features in the immediate surroundings. This is, in particular, true for those species whose home range is larger than the project site, or those for which only one individual or a pair can live at the project site [62].

Third, a species may occur in the focal area but dispersal barriers may prevent it to reach the project site. Studies in urban areas have shown that colonization of patches depends on barriers that limit dispersal (e.g., roads [63]), and on corridors that facilitate movement between patches and connectivity with neighboring areas $[64,65]$. In addition to these limitations imposed by the urban structure, species-specific traits also determine the ability of species to reach suitable habitat in urban areas. These include home range $[47,66]$, dispersal ability $[47,66-70]$ and sensitivity towards barriers $[47,54,71-73]$.

Thus, it is necessary to compare the ecological traits and requirements of the species with the limitations of the project site, including patch area and connectivity, corridors and barriers, and available habitat types and structures (Table 1, Figure 4). To this end, the project site and its surroundings need to be assessed in detail by analyzing available digital maps, such as land use maps, biotope maps, treemaps and aerial imagery. This assessment is complemented through a visit to the project site 
during which species and habitats are directly recorded. In addition, it may be necessary to consult with landowners of the neighboring areas in order to ensure that landscape connectivity and corridors will persist in the future. The local species potential will thus only retain species from the regional species pool that is likely to (a) colonize the project site, and (b) survive at the project site, based on the habitat structures available around the project site and provided that the developer will upgrade the site for the requirements of the species.

Table 1. Summary of factors limiting the suitability of a project site for particular species, thus reducing the regional species pool to those species that can reasonably be considered a potential target species, i.e., the local species potential.

\begin{tabular}{|c|c|c|c|c|}
\hline & $\begin{array}{l}\text { Limiting Factors of } \\
\text { a Site and Its } \\
\text { Surroundings }\end{array}$ & $\begin{array}{l}\text { Requirements of the } \\
\text { Species that May } \\
\text { Limit its Occurrence }\end{array}$ & $\begin{array}{l}\text { Necessary Checks of Existing } \\
\text { Habitat Conditions (Examples) }\end{array}$ & $\begin{array}{l}\text { Necessary Checks of } \\
\text { Development Plans } \\
\text { (Examples) }\end{array}$ \\
\hline \multirow{4}{*}{ 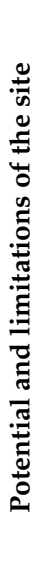 } & \multirow{3}{*}{$\begin{array}{l}\text { Habitat structures } \\
\text { such as } \\
\text { old trees, } \\
\text { large water bodies } \\
\text { (e.g., lakes, rivers), } \\
\text { soil composition, } \\
\text { tree density }\end{array}$} & $\begin{array}{l}\text { Particular feeding } \\
\text { preferences, need of } \\
\text { resting or hibernation } \\
\text { sites, breeding sites, } \\
\text { and resting sites }\end{array}$ & $\begin{array}{l}\text { Do mature trees with cavities } \\
\text { exist that can serve as breeding } \\
\text { or resting sites for woodpeckers } \\
\text { or bats? } \\
\text { Are there large water bodies that }\end{array}$ & $\begin{array}{l}\text { Which ecological } \\
\text { requirements can already } \\
\text { be fulfilled through } \\
\text { existing habitat } \\
\text { structures? }\end{array}$ \\
\hline & & $\begin{array}{l}\text { Note that habitat } \\
\text { requirements may }\end{array}$ & $\begin{array}{l}\text { fulfill the habitat requirements } \\
\text { of target amphibians? }\end{array}$ & \multirow{2}{*}{$\begin{array}{l}\text { Which requirements can } \\
\text { be fulfilled during the } \\
\text { development? } \\
\text { Which habitat } \\
\text { requirements of a species } \\
\text { are not realizable? }\end{array}$} \\
\hline & & $\begin{array}{l}\text { differ between life } \\
\text { cycle stages of the } \\
\text { same species. }\end{array}$ & $\begin{array}{l}\text { Is the tree density at the project } \\
\text { site high enough to fulfill the } \\
\text { habitat requirements of } \\
\text { forest species? }\end{array}$ & \\
\hline & $\begin{array}{l}\text { Transport } \\
\text { infrastructure, traffic, } \\
\text { pollution, noise, light }\end{array}$ & $\begin{array}{l}\text { Shelter from } \\
\text { disturbances }\end{array}$ & $\begin{array}{l}\text { Are disturbances likely to } \\
\text { interfere with the life-cycle of } \\
\text { a species? }\end{array}$ & \\
\hline 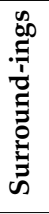 & $\begin{array}{l}\text { Size of project site, } \\
\text { landscape connectivity }\end{array}$ & Home range & $\begin{array}{l}\text { Are home range requirements of } \\
\text { a species met? }\end{array}$ & $\begin{array}{l}\text { Do land-use plans } \\
\text { ensure that landscape } \\
\text { connectivity, corridors } \\
\text { will be maintained? }\end{array}$ \\
\hline \multirow{2}{*}{ 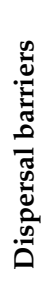 } & $\begin{array}{l}\text { Corridors to and } \\
\text { connectivity with } \\
\text { relevant areas, such as } \\
\text { gardens, backyards, } \\
\text { parks, forests }\end{array}$ & Dispersal ability & $\begin{array}{l}\text { Can species reach the project site } \\
\text { through existing corridors? }\end{array}$ & \multirow{2}{*}{$\begin{array}{l}\text { Is joint management } \\
\text { of connected } \\
\text { areas possible? } \\
\text { Will barriers be removed } \\
\text { in the future? }\end{array}$} \\
\hline & Barriers & Sensitivity to barriers & $\begin{array}{l}\text { Do barriers need to be removed } \\
\text { in order to allow the } \\
\text { immigration of the species? }\end{array}$ & \\
\hline
\end{tabular}




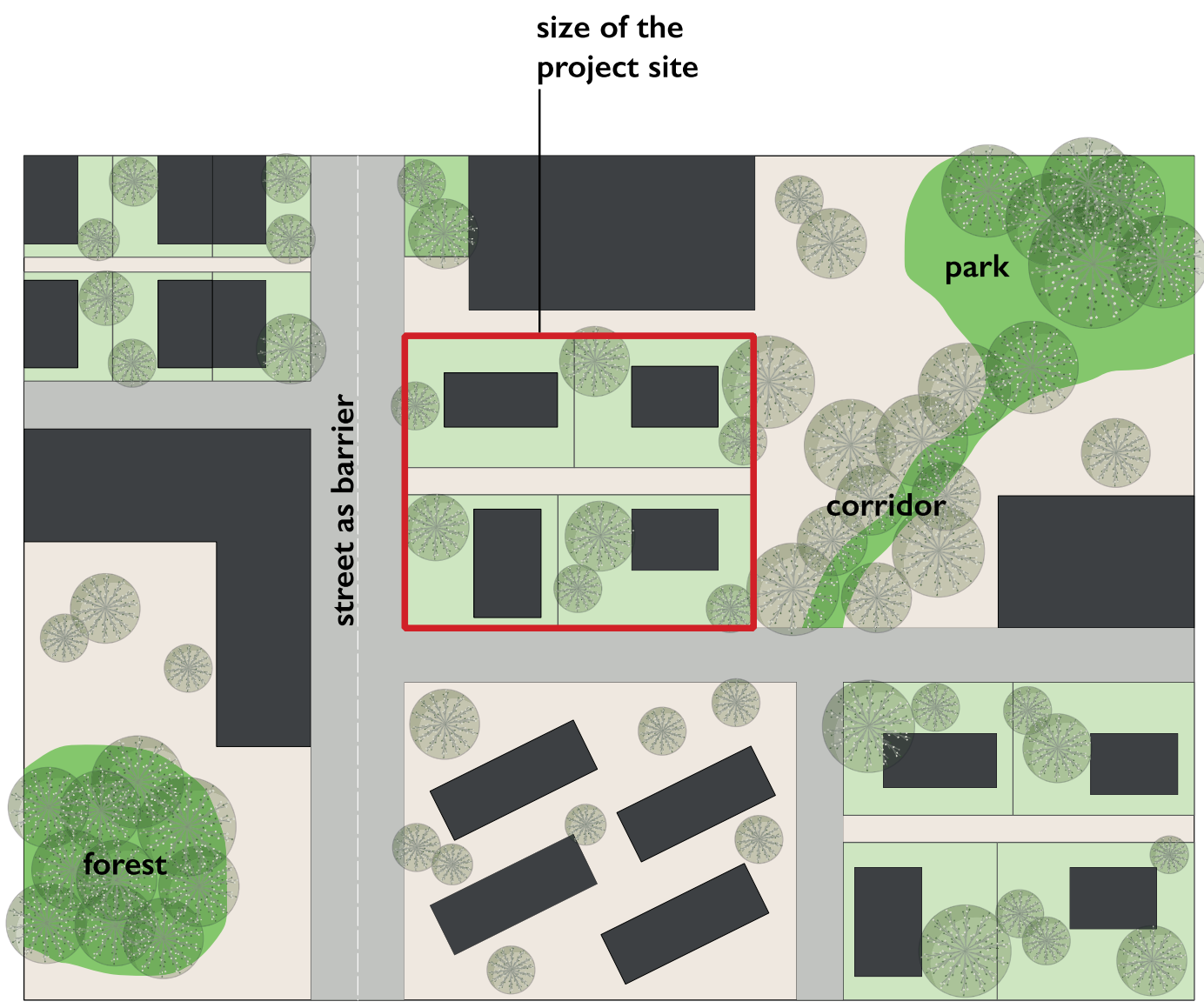

Figure 4. Site limitations derived from the urban structure at the project site for a potential target species that live in forest and park habitat: Forest, i.e., suitable habitat, street as a barrier to project site, the corridor from park to project site. Black blocks denote existing developments. In this example, the species can only reach the project site from the East, through the corridor.

\subsection{From the Local Species Potential to Target Species Selection}

The local species potential only retains species for which all ecological requirements can theoretically be fulfilled. Still, not all of these species may be suitable target species as we have not yet considered the human factor, which is important in urban environments. To this end, the attitude of humans towards the species needs to be assessed. We suggest analyzing those species traits that determine the attitude of humans towards them. These include their observability, potential benefits that humans may derive from a species, and potential conflicts between a species and humans (Table 2). Consideration of these traits will further limit the number of species that can be chosen as target species. The final step is the participative selection of target species for the development, where stakeholder demands play an important role. 
Table 2. Socio-cultural aspects to evaluate the relationship between animals and humans. Examples are given that may influence how well a species can be observed, of benefits that urban citizens may experience when interacting with animals, and of potential conflicts.

\begin{tabular}{clll}
\hline $\begin{array}{l}\text { Category of } \\
\text { Interaction }\end{array}$ & \multicolumn{1}{c}{ Examples } & \multicolumn{1}{c}{ Species Traits } & \multicolumn{1}{c}{ Examples of Species } \\
\hline Observability & $\begin{array}{l}\text { observability without technical } \\
\text { equipment recognisability change } \\
\text { in observability with season } \\
\text { (e.g., hibernation, breeding period) }\end{array}$ & $\begin{array}{l}\text { color, size, activity period } \\
\text { (day/night), single or in } \\
\text { groups, vocalizations } \\
\text { distinct patterns or features } \\
\text { migration, hibernation }\end{array}$ & $\begin{array}{l}\text { song of songbirds eye } \\
\text { patterns on butterfly wings } \\
\text { migratory behavior of } \\
\text { songbirds mating ritual } \\
\text { of hedgehogs }\end{array}$ \\
\hline \multirow{5}{*}{ Benefits } & $\begin{array}{l}\text { Regulating Services: pollination } \\
\text { decomposition pest control seed } \\
\text { dispersal Cultural Services: } \\
\text { aesthetic value health and wellbeing } \\
\text { educational value cultural value } \\
\text { symbolic value sense of place }\end{array}$ & $\begin{array}{l}\text { diet foraging mode and site } \\
\text { depiction on flags, emblems, } \\
\text { logos in the region }\end{array}$ & $\begin{array}{l}\text { pollination by bees } \\
\text { earthworm activity } \\
\text { consumption of mosquitoes } \\
\text { by bats seed storage by } \\
\text { squirrels heraldic animals }\end{array}$ \\
\hline \multirow{2}{*}{ Conflicts } & $\begin{array}{l}\text { negative impacts on human health } \\
\text { economic damage negative } \\
\text { psychological effects negative } \\
\text { impact on other species }\end{array}$ & $\begin{array}{l}\text { disease vectors dangerous } \\
\text { predators storage pests } \\
\text { damage to infrastructure } \\
\text { traits related to inflicting } \\
\text { fear, phobia (in spiders) } \\
\text { invasive species }\end{array}$ & $\begin{array}{l}\text { lice, tick, mosquito wolf, } \\
\text { bear, wild boar, rice weevil, } \\
\text { clothes moth, rat, } \\
\text { woodpecker holes } \\
\text { in facades snakes, } \\
\text { spiders raccoon, nutria }\end{array}$ \\
\hline
\end{tabular}

\subsubsection{Evaluating the Human-Animal Relationship: Species' Socio-Cultural Traits}

Human perception of animals is complex and may elicit positive or negative feelings, like joy, but also fear and disgust [74]. In addition, some species are rated highly, because they provide important ecosystem services. For example, biodiversity may provide regulating ecosystem services, may contribute to the wellbeing of city dwellers [75], or may have high cultural or symbolic value [76,77]. On the other hand, disservices may also exist as some species, e.g., parasites or large carnivores, may impair human health or lead to dangerous encounters for humans [78,79]. Some species may also be considered a nuisance because they are perceived as noisy or dirty [80]. Thus, human values limit the acceptance of urban nature. Not all animals that could live in the city for biological reasons are approved or tolerated by urban inhabitants. Rats or pigeons are generally undesired even though they can cope very well with the conditions in the city, while squirrels or small songbirds, for example, have a positive record [81]. Perception of species and the ability to identify them depend on the taxonomic group and on how evenly species are distributed, i.e., rare species and species hard to detect may not be perceived by most people $[74,82]$. Species that are easy to perceive and observe, for example with colorful patterns, have a high recognition value and contribute to nature experience by urban citizens [83]. These considerations need to be taken into account when choosing target species for urban development projects, in order to maximize positive human-wildlife interactions and to minimize human-wildlife conflict. Three major aspects that influence human-wildlife interactions in urban areas emerge. These are (a) the observability of a species or taxonomic group, (b) potential benefits to human health and other ecosystem services and (c) potential conflicts or disservices (Table 2).

Therefore in this step, species or entire taxonomic groups-depending on the available literature-need to be evaluated according to traits that determine their observability and potential benefits or conflicts in general (Table 2). Observability mainly includes outward species traits, such as size, color, patterns or song. Potential benefits of species or taxonomic groups consider positive effects on humans or open spaces and are classified into regulating and cultural benefits according to their function as ecosystem services. Conflicts explore potential negative effects of species or taxonomic groups on humans or open spaces. This also considers the potential of a species to elicit negative feelings in humans and attitudes towards different species [81]. At the end of this step, it should be clear which species may be generally better or less well-suited as target species for a project from a human point of view. Because this evaluation will depend on the cultural context in which the evaluation takes 
place, e.g., in Western Europe [84,85], but not necessarily on the specific urban development, this step needs to be done only once for each species and the results can be assembled in a database that can be used in further projects. Exceptions may be situations where the development concerns an area with a different or mixed cultural context, e.g., the building of an apartment block where tenants may also come from outside Europe, or the business site of a foreign, e.g., Asian company. Here, the attributes of the species may be different or more diverse.

\subsubsection{Evaluating the Human-Animal Relationship: Stakeholder Analysis and Stakeholder Demands}

How humans perceive animals and benefits from biodiversity may to some extent not only depend on the cultural, but also socio-demographic background of an individual [86] and the context in which they interact with animals [74]. Furthermore, depending on their background, humans differ in how well they can assess the diversity of animals or plants in their environment and this, in turn, may have effects on self-reported well-being and interaction with wildlife [74]. To facilitate the final discussion and participatory selection of target species, stakeholders and their demands need to be analyzed. Developers, architects and landscape architects will be the main stakeholders in most urban development projects. However, depending on the project type, further stakeholders may be considered, such as residents, citizens, NGOs, and local authorities. Tools for evaluation of stakeholder attitudes and demands depend on the stakeholders involved and may range from direct dialogue to surveys, to considering data on socio-demographic structure, economic wealth, ecological knowledge and education (for a review of further factors that influence human-wildlife interactions see [74]). In this step, the project budget and organizational details should also be assessed (Table 3).

Table 3. Examples for location and project specific stakeholder demands.

\begin{tabular}{c}
\hline Attitudes Towards Wildlife Occurrence at the Project Site, e.g., in Residential Areas \\
Attitude towards ecological topics and natural design and landscaping \\
Desired use of space (e.g., play space concept) \\
Aesthetic demands (e.g., design concept) \\
Requirements for maintenance of buildings and open space \\
Budget for implementation of measures and maintenance thereof \\
Administrative requirements, e.g., compensatory measures, species protection legislation \\
Local peculiarities or characteristics of the city or region with respect to certain species or taxonomic \\
groups (e.g., cultural and historical aspects)
\end{tabular}

\subsubsection{Prioritization of Species: Balancing Feasibility and Stakeholder Demands}

Structured decision making offers a useful tool to balance different needs and prioritize species and is increasingly used in solution finding for complex problems at the interface between ecology and society [87]. In a consequence table, the identified ecological, socio-cultural and project-specific requirements are unified to facilitate participatory target species selection (Table 4). Specifically, the objectives of the project with respect to wildlife inclusion are listed and each species is evaluated according to predefined criteria. For example, economic feasibility is evaluated, e.g., what are the costs to implement and maintain specific habitat structures? In the context of wildlife-inclusive design, it is also important to consider potential conflicts between habitat structures required by certain species and humans using the open space, i.e., not only the species has to be desirable, but also its required habitat structures. At the same time, potential solutions for these conflicts should be offered, e.g., pollution of facades by birds may be avoided through the application of excrement boards. Color-coding can then be used to identify species that have been positively evaluated with respect to most objectives. These are the most promising target species. The final selection of target species is based on the consequence table and the involvement of all project stakeholders. 
Table 4. Consequence table that unifies the identified ecological, socio-cultural and project-specific requirements to facilitate participatory target species selection.

\begin{tabular}{|c|c|c|c|}
\hline Objective & Measure & Species A & Species B \\
\hline $\begin{array}{l}\text { Provide all necessary habitat } \\
\text { structures for target species }\end{array}$ & $\begin{array}{l}\text { Costs of different habitat structures } \\
\text { (implementation and maintenance) }\end{array}$ & & \\
\hline $\begin{array}{l}\text { Fulfill functions of the open space } \\
\text { required by humans }\end{array}$ & $\begin{array}{l}\text { Conflicts between animal habitat } \\
\text { requirements and human open space } \\
\text { requirements (yes, no) }\end{array}$ & & \\
\hline Find solutions to avoid conflicts. & $\begin{array}{l}\text { Are there solutions available or can be } \\
\text { designed to avoid the negative effects } \\
\text { of a species? }\end{array}$ & & \\
\hline $\begin{array}{l}\text { Enable positive human-wildlife } \\
\text { interactions }\end{array}$ & $\begin{array}{l}\text { Observability of different species } \\
\text { (low, medium, high) }\end{array}$ & & \\
\hline $\begin{array}{l}\text { Generate benefits for the local } \\
\text { community at the project site }\end{array}$ & $\begin{array}{l}\text { Regulating or cultural services } \\
\text { delivered by species }\end{array}$ & & \\
\hline $\begin{array}{l}\text { Avoid conflicts between target } \\
\text { species and humans }\end{array}$ & $\begin{array}{l}\text { Probability of conflict } \\
\text { (low, medium, high) }\end{array}$ & & \\
\hline $\begin{array}{l}\text { Protect threatened species that are } \\
\text { present at the project site }\end{array}$ & $\begin{array}{l}\text { Protection status (e.g., IUCN and } \\
\text { country-specific species lists) }\end{array}$ & & \\
\hline Strengthen cultural identity & Local cultural/symbolic value & & \\
\hline
\end{tabular}

\subsubsection{Participative Selection of Target Species}

In a final step the expert professionals that are in charge of the selection process, e.g., planning offices or nature conservation authorities, will select target species together with the developer and the project-specific stakeholders, such as residents, architects, maintenance companies or housing associations. The extent of participation will depend on the specific project. The main goal of participation within wildlife-inclusive design is to increase the acceptance of wildlife and necessary measures to support wildlife within urban areas. Whether participation will be successful in increasing the acceptance of wildlife-inclusive design will mainly depend on the degree of empowerment of stakeholders.

Different levels of participation can be differentiated that vary in their degree of empowerment of stakeholders ('the ladder of participation', [88,89]). The foundation for any kind of participation in the sharing of information. When participation remains at this level, it is also referred to as 'tokenism' as those affected are not able to contribute to the decision making itself. In the context of wildlife-inclusive urban design, this may include access to information about the functions of different habitat structures for target species. A further stage of participation is consultation, where stakeholders have the possibility to comment on plans. In the context of wildlife-inclusive urban design, the consequence table developed in the previous step may be discussed with the stakeholders, but the final selection of species would lie with the experts and the developer. The highest level of participation is reached when stakeholders can use the shared information to actively engage in decision-making or in joint development of ideas. For wildlife-inclusive urban design, this would mean the pros and cons of different species are not only discussed with stakeholders, but the final choice would be made jointly. As the scale and context of wildlife-inclusive urban design projects will vary, the realizable degree of participation may vary too. The degree of participation that can be realized in a specific project may also depend on the time scale of the project and its available budget. The participation of stakeholders goes beyond the overall coordination of the selection process with the developer, which is not considered participation in this context. Distinct expectations are often responsible for the failure of participation. While stakeholders often expect joint decision-making, those in power often equate participation with information sharing [90]. Therefore, to avoid conflicts and misunderstandings, it is necessary to be clear about the degree of participation early on. 


\section{Conclusions and Open Questions}

Here we propose a conceptual framework for the selection of target species for urban development projects that considers the socio-ecological nature of urban environments. We ensure that target species for urban development are ecologically sensible, realizable with respect to design, feasible within the organizational framework of the project, e.g., budget, and socially accepted.

The selection process relies on close cooperation of developers, architects, landscape architects, and ecologists, who should form part of the design team. Some of the necessary selection steps are already part of the normal workflows of urban development projects. For example, architects and landscape architects commonly assess maps of the project site and its vicinity in detail during project development. So far, however, open space was only analyzed with respect to human needs, while now animal needs should also be considered, which requires the experience of ecologists.

We also suggest actively involving all project-relevant stakeholders in the final selection of target species. Many of them, e.g., in particular later tenants, will be crucial for stewardship and maintenance and thus, the long-term success of the wildlife-inclusive design. Communication with and involvement of stakeholders has been suggested to be key for successful wildlife management in urban areas [91]. In the selection procedure proposed here, participation is based on a well-prepared pre-selection of species that ensures that potential target species are ecologically and socially sensible and feasible. In addition, through structured decision making the pros and cons of different potential target species are transparently presented and based on objective and clear criteria. Thereby, stakeholders are given a true choice between different potential species and the best possible conditions for a successful agreement on a set of target species are given. However, in certain developments, some stakeholders may only appear post-construction, e.g., future residents of new builds. In these cases, post-construction information for example through educational programs may be applied [92].

More difficult may be the initial spatial localization of species through habitat types. In many countries, land use maps and terrestrial habitat maps exist [93]. However, caution has to be taken as land use maps represent their use for humans and may only have limited power for predicting animal occurrences [94]. Most habitat maps are based on vegetation types and do not necessarily reflect all habitat types that are relevant for animals. In addition, they often do not cover the whole city area, but only selected biotopes and traditional classifications may be inappropriate in urban environments [95]. New promising ways of capturing spatial heterogeneity of urban areas through remote sensing approaches have been proposed [96]. Whether they can predict the distribution of animals across urban landscapes still needs to be tested. Nevertheless, associations between land cover, block-scale vegetation, and bird communities have been found [28]. While GIS and remote-sensing based approaches are frequently used in conservations science to predict habitat suitability, we demonstrate that these approaches may also be valuable tools for wildlife-inclusive urban design in the built-up area of cities.

Built-up areas are novel urban ecosystems with no natural habitat equivalent [23]. Therefore, we think that a target species approach is most appropriate in urban environments. Nevertheless, as species are part of food webs, habitat for species that serve as food resources for the target species also need to be planned for. For example, to successfully establish songbirds at a project site, habitat for insects has to be created as well.

Author Contributions: Conceptualization B.A., T.E.H., C.J. and W.W.W.; methodology B.A., T.E.H., C.J. and W.W.W.; formal analysis M.H. and E.B.S.; data curation M.H. and E.B.S.; writing-original draft preparation B.A. and W.W.W.; writing-review and editing B.A., T.E.H., C.J., M.H., E.B.S. and W.W.W.; visualization M.H., E.B.S., T.E.H. and B.A.; supervision T.E.H. and W.W.W.; project administration T.E.H. and W.W.W.; funding acquisition T.E.H. and W.W.W.

Funding: Funding of B.A., C.J., and T.E.H. was provided by the Bundesamt für Naturschutz (BfN), FKZ351689216A.

Acknowledgments: We thank Alice Schröder and Florian Meyer, BfN, for advice and project supervision. We also thank Rebbeka Honecker for her input. We are grateful to the following institutions for providing digital monitoring data: Arachnologische Gesellschaft e.V. (AraGes), Bayerisches Landesamt für Umwelt (LfU Bayern), Freie und Hansestadt Hamburg Behörde für Umwelt und Energie (BUE), Landesamt für Umweltschutz Sachsen-Anhalt 
(LAU), Landesamt für Umwelt-Rheinland-Pfalz (LfU), Landesanstalt für Umwelt Baden-Württemberg (LUBW), Landesamt für Umwelt, Naturschutz und Geologie Mecklenburg-Vorpommern (LUNG), Landesamt für Natur, Umwelt und Verbraucherschutz Nordrhein-Westfalen (LANUV NRW), Landesamt für Vermessung, Geoinformation und Landentwicklung (LVGL, Saarland), Landesamt für Landwirtschaft, Umwelt und ländliche Räume- Schleswig Holstein, Niedersächsischer Landesbetrieb für Wasserwirtschaft, Küsten- und Naturschutz (NLWKN), Staatliche Vogelschutzwarte für Hessen, Rheinland-Pfalz und Saarland (VSWFFM).

Conflicts of Interest: The authors declare no conflict of interest.

\section{Appendix A}

\section{Appendix A.1. Design and Data Acquisition}

We tested the availability of data in six major German cities and their surroundings (Hamburg, Hannover, Ingolstadt, Kaiserslautern, Magdeburg, Frankfurt) affecting eleven German federal states. The selection of the surveyed cities was based on the availability of monitoring data from local authorities and adjusted to represent a cross-section of different federal states. All records of animal occurrences in a circular buffer of $50 \mathrm{~km}$ around the project-sites were requested from federal authorities. If the area of investigation stretched across more than one federal state, data for these parts was requested from the local authorities respectively. Additionally, we downloaded publicly available animal records from the Global Biodiversity Information Facility (GBIF, https://doi.org/10.15468/dl.dyw3ux) and requested data from the Arachnologische Gesellschaft e.V. (AraGes). Data from federal authorities and the AraGes cannot be published because of restriction set within the user agreement.

\section{Appendix A.2. Data Preparation}

To be able to compare and merge the data obtained from different sources, it was necessary to standardize the records. We chose the GBIF Backbone-Taxonomy as a classification system for taxonomic nomenclature as it is widely used, provides means to crosswalk names from one source to another, and allows taxonomic search, as well as reporting operations in a consistent way.

In a first step, negative and false records were excluded from the data sets obtained from governmental authorities, GBIF and AraGes. Negative records are entries in which the absence of a species was recorded. We treated records as false records if no clear taxonomic assignment was given or if the recorded species was not identified to at least the genus level. False records were, for example, empty entries or species records that only specified larger taxonomic groups above the genus level. After removing wrong and negative entries from the dataset all records were checked for misspellings of species names with the Global Names Resolver [97] and corrected if needed.

To avoid multiple counting of a species due to species-rank synonyms, all records were checked for nomenclatural relevance. Old names and synonyms were updated according to the GBIF-Backbone Taxonomy using the R-Package "taxize v0.95" [98]. In the next step, the attribute tables of the single datasets were adjusted to allow a merge of datasets from different authorities. This included deletion of not required columns, an implementation of additional taxonomic information, as well as a standardization of the record date. After this step, every record was attributed with the following information: "Species", “Genus", "Family", “Order", “Class", “Kingdom”, “Date of record”.

The preparation of the GBIF-dataset included the following steps. First, only records that lay inside the area of investigation were kept in the dataset. Second, only records with one of the following values as the basis of record were accepted: "Human observation", "Observation", "Machine observation", "Living specimen". This step was necessary to clear the dataset from fossil specimens or specimens held by collections and museums. After standardization records from local authorities, AraGes and GBIF were merged to one dataset on which the following analysis was performed.

Some records of the federal authorities were stored in other geometry types than point format. This was the case if for instance only coarse geographic locations (raster) or a stretch of water (line and polygon type geometry) were given as the location of the record without a geo-referenced point locality. For the spatial analysis, it was necessary that all records were available in point format. Following a 
recommendation of the federal authorities (pers. comm., NLKWN, Niedersachsen, 2018) all raster and line type records were transformed into point geometries by calculating the centroids of the geometries in Q-GIS v3.6.1 (QGIS Development Team 2019).

\section{Appendix A.3. Spatial Analysis}

Spatial analysis was carried out using the R-package "sf" [99]. Regional species pools were estimated in regular distances from the survey sites. For this, we buffered one hundred concentric circles with growing diameters around the sites. The smallest radius was $5 \mathrm{~km}$ and the largest one $50 \mathrm{~km}$, the remaining radii of the intervening circles were chosen to provide a constant increase in the survey area. In total, the area ranged from $78.53 \mathrm{~km}^{2}$ at $5 \mathrm{~km}$ radius to $7853 \mathrm{~km}^{2}$ at $50 \mathrm{~km}$. The species counts within radii were calculated by intersecting buffers with the prepared species occurrence data. In order to exclude outdated and potentially extinct populations from the analysis, this step was carried out with a reduced data set that consisted of entries only recorded after the year 1980. The analysis was run separately for every project site and for all taxonomic classes.

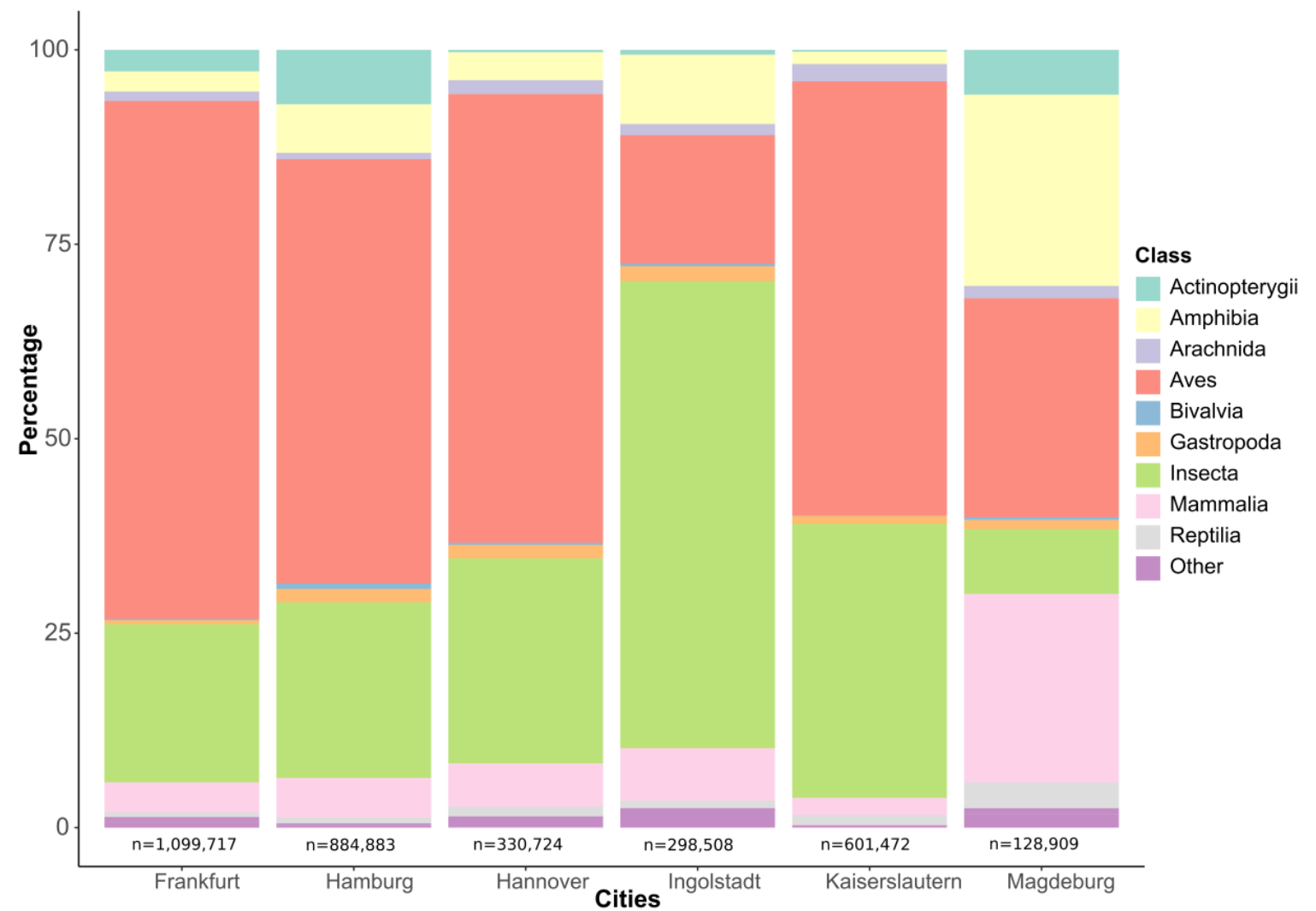

Figure A1. Species diversity at each project site presented as the percentage of different taxonomic groups of the total number of species records (n). Publicly available occurrence data includes many sightings of a plethora of taxonomic groups rather than numerous sightings of only a few attractive and therefore easy-to-spot species.

\section{References}

1. Díaz, S.; Settele, J.; Brondizio, E.S.; Ngo, H.T.; Guèze, M.; Agard, J.; Arneth, A.; Balvanera, P.; Brauman, K.A.; Butchart, S.H.M.; et al. IPBES. In Summary for Policymakers of the Global Assessment Report on Biodiversity and Ecosystem Services of the Intergovernmental Science-Policy Platform on Biodiversity and Ecosystem Services; IPBES Secretariat: Bonn, Germany, 2019.

2. Werner, P.; Zahner, R. Urban patterns and biological diversity: A review. In Urban Biodiversity and Design; Wiley: Oxford, UK, 2010; pp. 145-173. 
3. Kettel, E.F.; Gentle, L.K.; Quinn, J.L.; Yarnell, R.W. The breeding performance of raptors in urban landscapes: A review and meta-Analysis. J. Ornithol. 2018, 159, 1-18. [CrossRef]

4. Luck, G.W. A review of the relationships between human population density and biodiversity. Biol. Rev. 2007, 82, 607-645. [CrossRef] [PubMed]

5. Ives, C.D.; Lentini, P.E.; Threlfall, C.G.; Ikin, K.; Shanahan, D.F.; Garrard, G.E.; Bekessy, S.A.; Fuller, R.A.; Mumaw, L.; Rayner, L.; et al. Cities are hotspots for threatened species. Glob. Ecol. Biogeogr. 2016, 25, 117-126. [CrossRef]

6. Miller, J.R.; Hobbs, R.J. Conservation where people live and work. Conserv. Biol. 2002, 16, 330-337. [CrossRef]

7. Shaffer, M.L. Minimum population sizes for species conservation. BioScience 1981, 31, 131-134. [CrossRef]

8. Aronson, M.F.J.; Nilon, C.H.; Lepczyk, C.A.; Parker, T.S.; Warren, P.S.; Cilliers, S.S.; Goddard, M.A.; Hahs, A.K.; Herzog, C.; Katti, M.; et al. Hierarchical filters determine community assembly of urban species pools. Ecology 2016, 97, 2952-2963. [CrossRef]

9. Angold, P.G.; Sadler, J.P.; Hill, M.O.; Pullin, A.; Rushton, S.; Austin, K.; Small, E.; Wood, B.; Wadsworth, R.; Sanderson, R.; et al. Biodiversity in urban habitat patches. Sci. Total Environ. 2006, 360, 196-204. [CrossRef]

10. Beninde, J.; Veith, M.; Hochkirch, A. Biodiversity in cities needs space: A meta-Analysis of factors determining intra-Urban biodiversity variation. Ecol. Lett. 2015, 18, 581-592. [CrossRef]

11. Haaland, C.; van den Bosch, C.K. Challenges and strategies for urban green-Space planning in cities undergoing densification: A review. Urban For. Urban Green. 2015, 14, 760-771. [CrossRef]

12. De Coster, G.; De Laet, J.; Vangestel, C.; Adriaensen, F.; Lens, L. Citizen science in action-Evidence for long-Term, region-Wide House Sparrow declines in Flanders, Belgium. Landsc. Urban Plan. 2015, 134, 139-146. [CrossRef]

13. Sandifer, P.A.; Sutton-Grier, A.E.; Ward, B.P. Exploring connections among nature, biodiversity, ecosystem services, and human health and well-Being: Opportunities to enhance health and biodiversity conservation. Ecosyst. Serv. 2015, 12, 1-15. [CrossRef]

14. Nilon, C.H.; Aronson, M.F.J.; Cilliers, S.S.; Dobbs, C.; Frazee, L.J.; Goddard, M.A.; O'Neill, K.M.; Roberts, D.; Stander, E.K.; Werner, P.; et al. Planning for the future of urban biodiversity: A global review of city-Scale initiatives. Bioscience 2017, 67, 332-342. [CrossRef]

15. Filazzola, A.; Shrestha, N.; MacIvor, J.S. The contribution of constructed green infrastructure to urban biodiversity: A synthesis and meta-Analysis. J. Appl. Ecol. 2019, 56, 2131-2143. [CrossRef]

16. Garrard, G.E.; Williams, N.S.G.; Mata, L.; Thomas, J.; Bekessy, S.A. Biodiversity sensitive urban design. Conserv. Lett. 2017, 11, e12411. [CrossRef]

17. Weisser, W.; Hauck, T.E. Animal-Aided Design-Using a species life-Cycle to improve open space planning and conservation in cities and elsewhere. Biorxiv 2017, 1-14. (in press).

18. Snep, R.; Opdam, P. Integrating nature values in urban planning and design. In Urban Ecology; Gaston, K.J., Ed.; Cambridge University Press: Cambridge, UK, 2010; pp. 261-286.

19. Sodhi, N.S.; Ehrlich, P.R. Conservation Biology for All; Oxford University Press: Oxford, UK, 2010.

20. Brook, T. Conservation planning and priorities. In Conservation Biology for All; Sodhi, N.S., Ehrlich, P.R., Eds.; Oxford University Press: Oxford, UK, 2010; pp. 199-219.

21. Andelman, S.J.; Fagan, W.F. Umbrellas and flagships: Efficient conservation surrogates or expensive mistakes? Proc. Natl. Acad. Sci. USA 2000, 97, 5954-5959. [CrossRef]

22. Gossner, M.M.; Fonseca, C.R.; Pašalić, E.; Türke, M.; Lange, M.; Weisser, W.W. Limitations to the use of arthropods as temperate forests indicators. Biodivers. Conserv. 2014, 23, 945-962. [CrossRef]

23. Kowarik, I. Novel urban ecosystems, biodiversity, and conservation. Env. Pollut. 2011, 159, $1974-1983$. [CrossRef]

24. Box, J.; Harrison, C. Minimum targets for accessible natural greenspace in urban areas. Urban Wildl. News 1994, 11, 10-11.

25. Hunter, M.L.; Gibbs, J.P. Fundamentals of Conservation Biology; Wiley-Blackwell: Cambridge, UK, 2007.

26. Berkes, F. Rethinking Community-Based Conservation. Conserv. Biol. 2004, 18, 621-630. [CrossRef]

27. Otto, J.; Zerner, C.; Robinson, J.; Donovan, R.; Lavelle, M.; Villarreal, R.; Salafsky, N.; Alcorn, J.; Seymour, F.; Kleyneyer, C.; et al. Natural Connections: Perspectives in Community-Based Conservation; Island Press: Washington, DC, USA, 2013.

28. Nilon, C.H. Urban biodiversity and the importance of management and conservation. Landsc. Ecol. Eng. 2011, 7, 45-52. [CrossRef] 
29. Hostetler, M.E. The Green Leap: A Primer for Conserving Biodiversity in Subdivision Development, 1st ed.; University of California Press: Berkeley, CA, USA, 2012.

30. GBIF.Org GBIF Home Page. Available online: https://www.gbif.org (accessed on 24 September 2018).

31. Underwood, E.; Taylor, K.; Tucker, G. The use of biodiversity data in spatial planning and impact assessment in Europe. Res. Ideas Outcomes 2018, 4. [CrossRef]

32. Wüest, R.O.; Zimmermann, N.E.; Zurell, D.; Alexander, J.M.; Fritz, S.A.; Hof, C.; Kreft, H.; Normand, S.; Cabral, J.S.; Szekely, E.; et al. Macroecology in the age of Big Data-Where to go from here? J. Biogeogr. 2019, 1-12. Available online: https://onlinelibrary.wiley.com/doi/abs/10.1111/jbi.13633 (accessed on 4 December 2019). [CrossRef]

33. Cayuela, H.; Lambrey, J.; Vacher, J.-P.; Miaud, C. Highlighting the effects of land-Use change on a threatened amphibian in a human-Dominated landscape. Popul. Ecol. 2015, 57, 433-443. [CrossRef]

34. Albert, C.H.; Rayfield, B.; Dumitru, M.; Gonzalez, A. Applying network theory to prioritize multispecies habitat networks that are robust to climate and land-Use change. Conserv. Biol. 2017, 31, 1383-1396. [CrossRef]

35. Rhodes, M.; Wardell-Johnson, G. Roost tree characteristics determine use by the white-Striped freetail bat (Tadarida australis, Chiroptera: Molossidae) in suburban subtropical Brisbane, Australia. Austral. Ecol. 2006, 31, 228-239. [CrossRef]

36. Rhodes, M.; Wardell-Johnson, G.W.; Rhodes, M.P.; Raymond, B.E.N. Applying network analysis to the conservation of habitat trees in urban environments: A case study from Brisbane, Australia. Conserv. Biol. 2006, 20, 861-870. [CrossRef]

37. Threlfall, C.G.; Williams, N.S.G.; Hahs, A.K.; Livesley, S.J. Approaches to urban vegetation management and the impacts on urban bird and bat assemblages. Landsc. Urban Plan. 2016, 153, 28-39. [CrossRef]

38. Le Roux, D.S.; Ikin, K.; Lindenmayer, D.B.; Manning, A.D.; Gibbons, P. The value of scattered trees for wildlife: Contrasting effects of landscape context and tree size. Divers. Distrib. 2018, 24, 69-81. [CrossRef]

39. Carpaneto, G.M.; Mazziotta, A.; Coletti, G.; Luiselli, L.; Audisio, P. Conflict between insect conservation and public safety: The case study of a saproxylic beetle (Osmoderma eremita) in urban parks. J. Insect Conserv. 2010, 14, 555-565. [CrossRef]

40. Mason, J.; Moorman, C.; Hess, G.; Sinclair, K. Designing suburban greenways to provide habitat for forest-Breeding birds. Landsc. Urban Plan. 2007, 80, 153-164. [CrossRef]

41. Parker, T.S.; Nilon, C.H. Urban landscape characteristics correlated with the synurbization of wildlife. Landsc. Urban Plan. 2012, 106, 316-325. [CrossRef]

42. Turrini, T.; Knop, E. A landscape ecology approach identifies important drivers of urban biodiversity. Glob. Chang. Biol. 2015, 21, 1652-1667. [CrossRef] [PubMed]

43. Burghardt, K.T.; Tallamy, D.W.; Philips, C.; Shropshire, K.J. Non-Native plants reduce abundance, richness, and host specialization in lepidopteran communities. Ecosphere 2010, 1, 1-22. [CrossRef]

44. Concepción, E.D.; Götzenberger, L.; Nobis, M.P.; Bello, F.; Obrist, M.K.; Moretti, M. Contrasting trait assembly patterns in plant and bird communities along environmental and human-Induced land-Use gradients. Ecography 2017, 40, 753-763. [CrossRef]

45. Evans, K.L.; Chamberlain, D.E.; Hatchwell, B.J.; Gregory, R.D.; Gaston, K.J. What makes an urban bird? Glob. Chang. Biol. 2011, 17, 32-44. [CrossRef]

46. Croci, S.; Butet, A.; Clergeau, P. Does urbanization filter birds on the basis of their biological traits? Condor 2008, 110, 223-240. [CrossRef]

47. Grant, B.; Middendorf, G.; Colgan, M.; Ahmad, H.; Vogel, M. Ecology of urban amphibians and reptiles: Urbanophiles, urbanophobes, and the urbanoblivious In Urban Ecology: Patterns, Processes, and Applications; Oxford University Press: Oxford, UK, 2011.

48. Harrison, T.; Gibbs, J.; Winfree, R. Forest bees are replaced in agricultural and urban landscapes by native species with different phenologies and life-History traits. Glob. Chang. Biol. 2018, 24, 287-296. [CrossRef]

49. Jain, A.; Lim, F.K.S.; Webb, E.L. Species-Habitat relationships and ecological correlates of butterfly abundance in a transformed tropical landscape. Biotropica 2017, 49, 355-364. [CrossRef]

50. Lizee, M.H.; Mauffrey, J.F.; Tatoni, T.; Deschamps-Cottin, M. Monitoring urban environments on the basis of biological traits. Ecol. Indic. 2011, 11, 353-361. [CrossRef] 
51. Allen, A.P.; O'Connor, R.J. Hierarchical correlates of bird assemblage structure on northeastern USA lakes. Env. Monit. Assess. 2000, 62, 15-35. [CrossRef]

52. Jung, K.; Threlfall, C.G. Urbanisation and its effects on bats-A global meta-Analysis. In Bats in the Anthropocene: Conservation of Bats in a Changing World; Voigt, C.C., Kingston, T., Eds.; Springer International Publishing: Cham, Germany, 2016; pp. 13-33.

53. Threlfall, C.; Law, B.; Penman, T.; Banks, P.B. Ecological processes in urban landscapes: Mechanisms influencing the distribution and activity of insectivorous bats. Ecography 2011, 34, 814-826. [CrossRef]

54. Russo, D.; Ancillotto, L. Sensitivity of bats to urbanization: A review. Mamm. Biol. 2015, 80, $205-212$. [CrossRef]

55. Pollack, L.; Ondrasek, N.R.; Calisi, R. Urban health and ecology: The promise of an avian biomonitoring tool. Curr. Zool. 2017, 63, 205-212. [CrossRef]

56. Kight, C.R.; Swaddle, J.P. How and why environmental noise impacts animals: An integrative, mechanistic review. Ecol. Lett. 2011, 14, 1052-1061. [CrossRef]

57. Spoelstra, K.; van Grunsven, R.H.A.; Ramakers, J.J.C.; Ferguson, K.B.; Raap, T.; Donners, M.; Veenendaal, E.M.; Visser, M.E. Response of bats to light with different spectra: Light-Shy and agile bat presence is affected by white and green, but not red light. Proc. Biol. Sci. 2017, 284, 1855. [CrossRef]

58. Spoelstra, K.; van Grunsven, R.H.A.; Donners, M.; Gienapp, P.; Huigens, M.E.; Slaterus, R.; Berendse, F.; Visser, M.E.; Veenendaal, E. Experimental illumination of natural habitat-An experimental set-Up to assess the direct and indirect ecological consequences of artificial light of different spectral composition. Philos. Trans. B 2015, 370, 1667. [CrossRef]

59. Ouyang, J.Q.; de Jong, M.; van Grunsven, R.H.A.; Matson, K.D.; Haussmann, M.F.; Meerlo, P.; Visser, M.E.; Spoelstra, K. Restless roosts: Light pollution affects behavior, sleep, and physiology in a free-Living songbird. Glob. Chang. Biol. 2017, 23, 4987-4994. [CrossRef]

60. Manfrin, A.; Singer, G.; Larsen, S.; Weiß, N.; van Grunsven, R.H.A.; Weiß, N.-S.; Wohlfahrt, S.; Monaghan, M.T.; Hölker, F. Artificial light at night affects organism flux across ecosystem boundaries and drives community structure in the recipient ecosystem. Front. Environ. Sci. 2017, 5, 61. [CrossRef]

61. Knop, E.; Zoller, L.; Ryser, R.; Gerpe, C.; Hörler, M.; Fontaine, C. Artificial light at night as a new threat to pollination. Nature 2017, 548, 206. [CrossRef]

62. Hostetler, M.; Holling, C.S. Detecting the scales at which birds respond to structure in urban landscapes. Urban Ecosyst. 2000, 4, 25-54. [CrossRef]

63. Cox, D.T.C.; Inger, R.; Hancock, S.; Anderson, K.; Gaston, K.J. Movement of feeder-Using songbirds: The influence of urban features. Sci. Rep. 2016, 6, 37669. [CrossRef] [PubMed]

64. Shanahan, D.F.; Miller, C.; Possingham, H.P.; Fuller, R.A. The influence of patch area and connectivity on avian communities in urban revegetation. Biol. Conserv. 2011, 144, 722-729. [CrossRef]

65. Vergnes, A.; Viol, I.L.; Clergeau, P. Green corridors in urban landscapes affect the arthropod communities of domestic gardens. Biol. Conserv. 2012, 145, 171-178. [CrossRef]

66. Bergerot, B.; Fontaine, B.; Julliard, R.; Baguette, M. Landscape variables impact the structure and composition of butterfly assemblages along an urbanization gradient. Landsc. Ecol. 2011, 26, 83-94. [CrossRef]

67. De la Flor, Y.A.D.; Burkman, C.E.; Eldredge, T.K.; Gardiner, M.M. Patch and landscape-Scale variables influence the taxonomic and functional composition of beetles in urban greenspaces. Ecosphere 2017, 8, 11. [CrossRef]

68. Rochat, E.; Manel, S.; Deschamps-Cottin, M.; Widmer, I.; Joost, S. Persistence of butterfly populations in fragmented habitats along urban density gradients: Motility helps. Heredity 2017, 119, 328-338. [CrossRef]

69. Penone, C.; Kerbiriou, C.; Julien, J.F.; Julliard, R.; Machon, N.; Le Viol, I. Urbanisation effect on Orthoptera: Which scale matters? Insect Conserv. Divers. 2013, 6, 319-327. [CrossRef]

70. Munshi-South, J. Urban landscape genetics: Canopy cover predicts gene flow between white-Footed mouse (Peromyscus leucopus) populations in New York City. Mol. Ecol. 2012, 21, 1360-1378. [CrossRef]

71. Altringham, J.; Kerth, G. Bats and roads. In Bats in the Anthropocene: Conservation of Bats in A Changing World; Voigt, C.C., Kingston, T., Eds.; Springer International Publishing: Cham, Germany, 2016; pp. 53-62.

72. Rondinini, C.; Doncaster, C.P. Roads as barriers to movement for hedgehogs. Funct. Ecol. 2002, 16, 504-509. [CrossRef]

73. Johnson, C.D.; Evans, D.; Jones, D. Birds and roads: Reduced transit for smaller species over roads within an urban environment. Front. Ecol. Evol. 2017, 5, 36. [CrossRef] 
74. Pett, T.J.; Shwartz, A.; Irvine, K.N.; Dallimer, M.; Davies, Z.G. Unpacking the People-Biodiversity Paradox: A Conceptual Framework. Bioscience 2016, 66, 576-583. [CrossRef]

75. Fuller, R.A.; Irvine, K.N.; Devine-Wright, P.; Warren, P.H.; Gaston, K.J. Psychological benefits of greenspace increase with biodiversity. Biol. Lett. 2007, 3, 390-394. [CrossRef] [PubMed]

76. Schirpke, U.; Meisch, C.; Tappeiner, U. Symbolic species as a cultural ecosystem service in the European Alps: Insights and open issues. Landsc. Ecol. 2018, 33, 711-730. [CrossRef]

77. Millard, A. Cultural aspects of urban biodiversity. In Urban Biodiversity and Design; Müller, N., Werner, P., Kelcey, J.G., Eds.; Wiley: Oxford, UK, 2010; pp. 56-80.

78. Dunn, R.R. Global mapping of ecosystem disservices: The unspoken reality that nature sometimes kills us. Biotropica 2010, 42, 555-557. [CrossRef]

79. Barua, M.; Bhagwat, S.A.; Jadhav, S. The hidden dimensions of human-wildlife conflict: Health impacts, opportunity and transaction costs. Biol. Conserv. 2013, 157, 309-316. [CrossRef]

80. Belaire, J.A.; Westphal, L.M.; Whelan, C.J.; Minor, E.S. Urban residents' perceptions of birds in the neighborhood: Biodiversity, cultural ecosystem services, and disservices. Birds Connect Urban Resid. Biodivers. Ecosyst. Serv. 2015, 117, 192-202. [CrossRef]

81. Bjerke, T.; Østdahl, T. Animal-Related attitudes and activities in an urban population. Anthrozoös 2004, 17, 109-129. [CrossRef]

82. McGinlay, J.; Parsons, D.J.; Morris, J.; Hubatova, M.; Graves, A.; Bradbury, R.B.; Bullock, J.M. Do charismatic species groups generate more cultural ecosystem service benefits? Ecosyst. Serv. 2017, 27, 15-24. [CrossRef]

83. Southon, G.E.; Jorgensen, A.; Dunnett, N.; Hoyle, H.; Evans, K.L. Perceived species-Richness in urban green spaces: Cues, accuracy and well-Being impacts. Landsc. Urban Plan. 2018, 172, 1-10. [CrossRef]

84. Saw, L.E.; Lim, F.K.S.; Carrasco, L.R. The relationship between natural park usage and happiness does not hold in a tropical city-State. PLoS ONE 2015, 10, e0133781. [CrossRef] [PubMed]

85. Lindemann-Matthies, P.; Keller, D.; Li, X.; Schmid, B. Attitudes toward forest diversity and forest ecosystem services-A cross-Cultural comparison between China and Switzerland. J. Plant Ecol. 2013, 7, 1-9. [CrossRef]

86. Hosaka, T.; Sugimoto, K.; Numata, S. Childhood experience of nature influences the willingness to coexist with biodiversity in cities. Palgrave. Commun. 2017, 3, 17071. [CrossRef]

87. Robinson, K.F.; Fuller, A.K.; Hurst, J.E.; Swift, B.L.; Kirsch, A.; Farquhar, J.; Decker, D.J.; Siemer, W.F. Structured decision making as a framework for large-Scale wildlife harvest management decisions. Ecosphere 2016, 7, e01613. [CrossRef]

88. Arnstein, S.R. A ladder of citizen participation. J. Am. Inst. Plan. 1969, 35, 216-224. [CrossRef]

89. White, S.C. Depoliticising development: The uses and abuses of participation. Dev. Pract. 1996, 6, 6-15. [CrossRef]

90. Ukowitz, M.; Hübner, R. Interventionsforschung: Band 3: Wege der Vermittlung. Intervention-Partizipation; Springer Fachmedien Wiesbaden: Wiesbaden, Germany, 2018.

91. Jacobson, S.K.; Wald, D.M.; Haynes, N.; Sakurai, R. Urban wildlife communication and negotiation. In Urban Wildlife Conservation: Theory and Practice; McCleery, R.A., Moorman, C.E., Peterson, M.N., Eds.; Springer US: Boston, MA, USA, 2014; pp. 217-238.

92. Hostetler, M.; Swiman, E.; Prizzia, A.; Noiseux, K. Reaching residents of green communities: Evaluation of a unique environmental education program. Appl. Environ. Educ. Commun. 2008, 7, 114-124. [CrossRef]

93. EEA. Joint MNHN-EEA Report 2014: Terrestrial Habitat Mapping in Europe; An Overview. Copenhagen, Denmark, 2014. Available online: https:/www.eea.europa.eu/publications/terrestrial-habitat-mapping-ineurope (accessed on 5 December 2019).

94. Hostetler, M.; Knowles-Yanez, K. Land use, scale, and bird distributions in the Phoenix metropolitan area. Landsc. Urban Plan. 2003, 62, 55-68. [CrossRef]

95. Sukopp, H.; Weiler, S. Biotope mapping and nature conservation strategies in urban areas of the Federal Republic of Germany. Landsc. Urban Plan. 1988, 15, 39-58. [CrossRef]

96. Cadenasso, M.L.; Pickett, S.T.A.; Schwarz, K. Spatial heterogeneity in urban ecosystems: Reconceptualizing land cover and a framework for classification. Front. Ecol. Env. 2007, 5, 80-88. [CrossRef]

97. Bennett, D.J.; Sanders, J.; Hudson, L.N. Taxon Names Resolver: A Python Package for the Automatic Search of Taxon Names Against the Global Names Resolver; Zenodo, 2016. [CrossRef] 
98. Chamberlain, S.; Szoecs, E.; Foster, Z.; Arendsee, Z.; Boettiger, C.; Ram, K.; Bartomeus, I.; Baumgartner, J.; O'Donnell, J.; Oksanen, J.; et al. Taxize: Taxonomic Information from around the Web. R Package, Version 0.9.5; 2019. Available online: https://journal.r-project.org/archive/2018/RJ-2018-009/RJ-2018-009.pdf (accessed on 5 December 2019).

99. Pebesma, E. Simple features for R: Standardized support for spatial vector data. R J. 2018, 10, 439-446. [CrossRef]

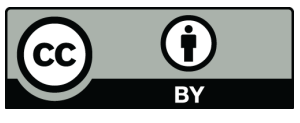

(C) 2019 by the authors. Licensee MDPI, Basel, Switzerland. This article is an open access article distributed under the terms and conditions of the Creative Commons Attribution (CC BY) license (http://creativecommons.org/licenses/by/4.0/). 